\title{
Changes in the Color and Physical Properties of Wood by High Temperature Heat Treatment
}

Jin, Taiquan

Laboratory of Wood Science, Department of Forest and Forest Product Science, Faculty of Agriculture, Kyushu University | Department of Wood Science, College of Agriculture, Chonbuk National University

\section{Kang, Chun-Won}

Laboratory of Wood Science, Department of Forest and Forest Product Science, Faculty of Agriculture, Kyushu University | Department of Housing Environmental Design, and Research Institute of Human Ecology, College of Human Ecology, Chonbuk National University

\section{Lee, Nam-Ho}

Department of Wood Science, College of Agriculture, Chonbuk National University | Laboratory of Wood Science, Department of Forest and Forest Product Science, Faculty of Agriculture, Kyushu University

\section{Kang, Ho-Yang}

Laboratory of Wood Science, Department of Forest and Forest Product Science, Faculty of Agriculture, Kyushu University | Department of Forest Products, College of Agriculture and Life Science, Chungnam National University

他

https://doi.org/10.5109/19541

出版情報 : 九州大学大学院農学研究院紀要. 56 (1)，pp. 129-137，2011-02. Faculty of Agriculture， Kyushu University

バージョン :

権利関係 : 


\title{
Changes in the Color and Physical Properties of Wood by High Temperature Heat Treatment
}

\author{
Taiquan JIN ${ }^{1}$, Chun-Won KANG ${ }^{2 *}$, Nam-Ho LEE ${ }^{1}$, Ho-Yang KANG ${ }^{3}$ \\ and Junji MATSUMURA ${ }^{3}$
}

\author{
Laboratory of Wood Science, Department of Forest and Forest Product Science, \\ Faculty of Agriculture, Kyushu University, Fukuoka 812-8581, Japan \\ (Received October 28, 2010 and accepted November 8, 2010)
}

\begin{abstract}
We analyzed changes in the color and physical properties by high temperature heat treated woods at several treatment conditions, performing regression analyses on the basic color variables $\mathrm{L}^{*}$, $\mathrm{a}^{*}$ and $\mathrm{b}^{*}$, and investigating the physical properties changes.

Four species of wood, Pine, Larch, Spruce and Yellow Poplar, were heat treated at five different temperatures, $150{ }^{\circ} \mathrm{C}, 170{ }^{\circ} \mathrm{C}, 190^{\circ} \mathrm{C}, 210^{\circ} \mathrm{C}$ and $230{ }^{\circ} \mathrm{C}$, for three different times: $2 \mathrm{~h}, 4 \mathrm{~h}$ and $6 \mathrm{~h}$.

We compared the control and heat treated specimens in terms of changes in the color and physical properties, such as the mass loss, the equilibrium moisture content (EMC), and the modulus of rupture (MOR) values. The color and physical properties were analyzed using a multiple stepwise regression based on the basic color variables $\mathrm{L}^{*}, \mathrm{a}^{*}$ and $\mathrm{b}^{*}$ as independent variables
\end{abstract}

Keywords: heat treated wood, mass loss, EMC, water absorption, swelling, MOR (modulus of rupture)

\section{INTRODUCTION}

Wood is used as a construction material because of its appearance, good mechanical properties and durability. However, it is a hygroscopic material in that the dimensions changes due to humid environments and it is vulnerable to mold and other fungi infestations. One solution is heat treatment, which enables physical modifications without the addition of chemicals. Although this technique decreases the hygroscopicity while improving the dimensional stability, biological durability and enhanced weather resistance, but may be reduce the mechanical resistance of the bending strength (Stamm et al., 1946; Stamm 1956; Viitaniemi et al., 1997; Kubojima et al., 2000; Jamsa and Viitaniemi, 2001; Rapp A. O. 2001; Kamdem et al., 2002; Bekhta and Niemz, 2003; MetsaKortelainen et al., 2006; Esteves et al., 2007).

Wood is a complex polymeric material which consists primarily of cellulose, hemicellulose and lignin, with a minor proportion of extractives. When wood is heated, its components degrade and reform. The hemicelluloses are the first to degrade. Hemicelluloses deacetylate and the released acetic acid act as a depolymerization catalyst (Tjeerdsma et al., 1998; Sivonen et al., 2002). Degraded hemicelluloses change the hygroscopic behavior of wood,

\footnotetext{
1 Department of Wood Science, College of Agriculture, Chonbuk National University, Jeonju 561-756, Korea

2 Department of Housing Environmental Design, and Research Institute of Human Ecology, College of Human Ecology, Chonbuk National University, Jeonju 561-756, Korea

Department of Forest Products, College of Agriculture and Life Science, Chungnam National University, Daejeon 305-764, Korea

${ }^{4}$ Laboratory of Wood Science, Division of Sustainable Bioresources Science, Department of Agro-environmental Sciences, Faculty of Agriculture, Kyushu University, Fukuoka 812-8581, Japan

* Corresponding author (E-mail: kcwon@jbnu.ac.kr)
}

which in turn decreases the equilibrium of the moisture content. Heat treatments have less effect on cellulose and lignin. Cellulose crystallinity increases due to the degradation of amorphous cellulose and the $\beta-\mathrm{O}-4$ linkages in lignin and the reduction in methoxyl leads to a more condensed structure (Wikberg and Maunu, 2004).

Previous studies have argued that color is one of the important properties of wood, and that heat-treated wood darkens (Mitsui et al., 2001; Bekhta and Niemz, 2003). Therefore, many studies have used color as a predictor of wood properties, such as mechanical resistance (Bekhta and Niemz, 2003; Johansson and Moren, 2006), or as a factor in heat-treated wood characterization (Bruno Esteves et al., 2008). Color measurement uses small samples and is a non-destructive method. Color properties are often used for analysis in the food industry and have successfully predicted food degradation.

Most studies have measured wood color using the CIELab method of $\mathrm{L}^{*}, \mathrm{a}^{*}$ and $\mathrm{b}^{*}$, and have calculated the difference between the lightness $\Delta \mathrm{L}^{*}$ and the total difference of color $\Delta \mathrm{E}$, analyzing the relationships between $\Delta \mathrm{L}^{*}$ and the wood's properties or $\Delta \mathrm{E}$ and the wood's properties (Johansson and Moren, 2006).

Thus, this studies analyzed the color changes, mass loss, EMC, swelling and modulus of rupture (MOR) changes of four species of heat-treated woods, at five different temperatures $\left(150{ }^{\circ} \mathrm{C}, 170{ }^{\circ} \mathrm{C}, 190{ }^{\circ} \mathrm{C}, 210^{\circ} \mathrm{C}\right.$ and $230^{\circ} \mathrm{C}$ ) and three different times $(2 \mathrm{~h}, 4 \mathrm{~h}$ and $6 \mathrm{~h}$ ) in terms of the variations in the relationships between the three basic color variables and the physical properties.

\section{MATERIALS AND METHODS}

\section{Sample specimens}

Pine, Larch, Spruce and Yellow Poplar were cut parallel to the fiber direction into $20 \mathrm{~mm} \times 20 \mathrm{~mm} \times 30 \mathrm{~mm}$ (tangential $\times$ radial $\times$ longitudinal) to determine the mass 
loss and equilibrium moisture content (EMC) changes, $30 \mathrm{~mm} \times 30 \mathrm{~mm} \times 15 \mathrm{~mm}$ (tangential $\times$ radial $\times$ longitudinal) for the dimensional stability test and $20 \mathrm{~mm} \times$ $20 \mathrm{~mm} \times 320 \mathrm{~mm}$ (tangential $\times$ radial $\times$ longitudinal $)$ to test for the bending strength. Every sample was randomly divided into 15 treatment groups of 10 specimens each. A control group comprised of 10 specimens of untreated samples was also examined.

\section{Heat treatment}

Prior to the heat treatment, the samples were dried until their moisture content was less than 15\%, except for the samples for mass loss. Splitting would occur if the moisture content of the material were too high (MC $>15 \%$ ) before the heat treatment. The mass loss samples were oven dried and the weights were recorded.

Heat treatments were carried out at five different temperatures of $150{ }^{\circ} \mathrm{C}, 170{ }^{\circ} \mathrm{C}, 190^{\circ} \mathrm{C}, 210^{\circ} \mathrm{C}$ and $230{ }^{\circ} \mathrm{C}$, and at three different times of $2 \mathrm{~h}, 4 \mathrm{~h}$ and $6 \mathrm{~h}$ in a laboratory type heating unit controlled to an accuracy of $\pm 1{ }^{\circ} \mathrm{C}$ under atmospheric pressure. After the treatments, the temperature was decreased over a period of 24 hours.

\section{Color measurement}

The color of the specimens was measured using a spectrophotometer (KONICA MINOLTA CR-400/410) with a D65 light source. In this color space, color is defined by its cartesian chromatic coordinates. The lightness L*, varies from 0 (black) to 100 (white), and the $\mathrm{a}^{*}$ and $\mathrm{b}^{*}$ coordinates define the chromaticity plane. The colors varied from green to red along the $\mathrm{a}^{*}$ axis and from blue to yellow along the $\mathrm{b}^{*}$ one. The sensor head of the spectrophotometer was $8 \mathrm{~mm}$ in diameter, which was sufficient to eliminate the influence of early and late wood variation, because the average annual ring width was $1.0 \mathrm{~mm}$ and the specimens had a homogeneous grain. The CIELab color parameters ( $\left.L^{*}, a^{*}, b^{*}\right)$ were used to express color change. From the $\mathrm{L}^{*}, \mathrm{a}^{*}$ and $\mathrm{b}^{*}$ values obtained, the differences in color parameters $\Delta \mathrm{L}^{*}, \Delta \mathrm{a}^{*}$, $\Delta \mathrm{b}^{*}$ and total color difference $(\Delta \mathrm{E})$ were calculated using the following formulae:

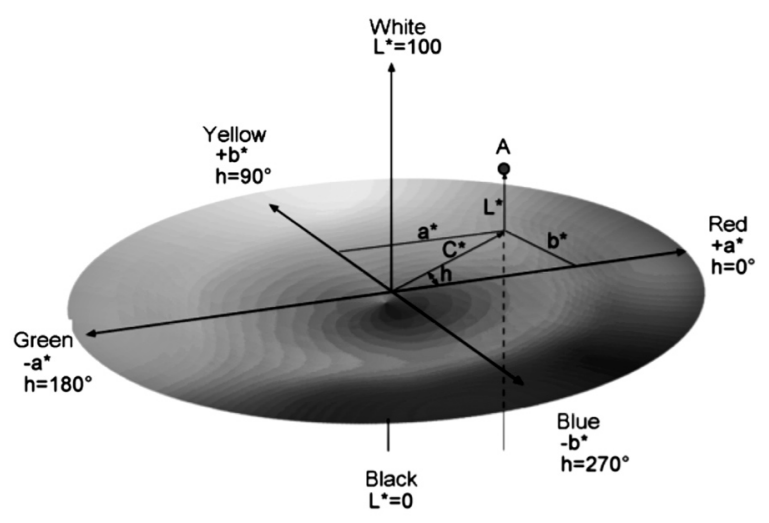

Fig. 1. The three-dimensional CIEL*a*b* color space. The $\mathrm{L}^{*}$ coordinate is the level of lightness. The $a^{*}$ and $b^{*}$ coordinates give the color of the measurement. (Adapted from internet)

$$
\begin{aligned}
& \Delta \mathrm{L}^{*}=\mathrm{L}^{* 1}-\mathrm{L}^{* 0} \\
& \Delta \mathrm{a}^{*}=\mathrm{a}^{* 1}-\mathrm{a}^{* 0} \\
& \Delta \mathrm{b}^{*}=\mathrm{b}^{* 1}-\mathrm{b}^{* 0} \\
& \Delta \mathrm{E}=\left(\Delta \mathrm{L}^{* 2}+\Delta \mathrm{a}^{* 2}+\Delta \mathrm{b}^{* 2}\right)^{1 / 2} \\
& \text { where } \\
& \mathrm{L}^{* 1}: \mathrm{L}^{*} \text { values after heat treatment } \\
& \mathrm{a}^{* 1}: \mathrm{a}^{*} \text { values after heat treatment } \\
& \mathrm{b}^{* 1}: \mathrm{b}^{*} \text { values after heat treatment } \\
& \mathrm{L}^{* 0}: \mathrm{L}^{*} \text { values before heat treatment } \\
& \mathrm{a}^{* 0}: \mathrm{a}^{*} \text { values before heat treatment } \\
& \mathrm{b}^{* 0}: \mathrm{b}^{*} \text { values before heat treatment. }
\end{aligned}
$$

\section{Mass loss and equilibrium moisture content}

The equilibrium moisture content (EMC) was defined as the moisture content when the wood reached a constant weight. The treated wood samples were conditioned in a humidity chamber at $40 \pm 1{ }^{\circ} \mathrm{C}$ temperature and $75 \pm 2 \%$ and $90 \pm 2 \%$ relative humidity and weighed every six hours until a constant weight was obtained. After which the wood samples were weighed and then oven dried at $103^{\circ} \mathrm{C}$ for 48 hours and weighed again. The mass loss and EMC were estimated according to the formula:

$$
\begin{aligned}
& \text { Mass } \operatorname{Loss}(\%)=\frac{M_{1}-M_{o}}{M_{o}} \times 100 \\
& \operatorname{EMC~}(\%)=\frac{M_{r}-M_{o}}{M_{o}} \times 100
\end{aligned}
$$

Where $\mathrm{M}_{1}$ : the weight of the oven-dried wood before the heat treatment

$\mathrm{M}_{\mathrm{o}}$ : the weight of the oven dried heat treated wood

$\mathrm{M}_{\mathrm{r}}$ : the weight of the heat treated wood with the moisture content.

\section{Soaking/Oven Drying Test}

After the heat treatment, the conditioning under atmosphere pressure and in the presence of air, the swelling thickness and water absorption ratios were evaluated using a soaking/oven drying test. All of the treated and untreated specimens were saturated with distilled water. The water absorption and thickness swelling ratios were measured after soaking the samples in distilled water for 48 hours. The cross-section, longitudinal and volume (v) dimensions of the saturated specimens were then determined, after which all of the specimens were oven-dried to constant weights. After these tests, the swelling and water absorption were calculated as:

$$
\mathrm{W}_{\mathrm{a}}=\frac{\mathrm{W}_{\mathrm{w}}-\mathrm{W}_{\mathrm{o}}}{\mathrm{W}_{\mathrm{o}}} \times 100
$$

where $\mathrm{W}_{\mathrm{a}}$ : Water absorption ratio of the specimens; $\mathrm{W}_{\mathrm{w}}$ : Weight of the wet samples;

$\mathrm{W}_{\mathrm{o}}$ : Weight of the oven-dried samples.

Swelling $=\frac{l_{\mathrm{s}}-l_{\mathrm{o}}}{l_{\mathrm{o}}} \times 100$

Where $l_{\mathrm{s}}$ : Length of the swollen samples $l_{0}$ : Length of the oven-dried samples. 


\section{Three point bending test}

Bending tests were performed using a universal testing machine (AGS-1000G, Shimatsu Corporation). Ten samples were conditioned at $65 \pm 2 \%$ relative humidity and room temperature for each set of parameters. A vertical force, exerted by a cross head, was applied to the middle of the upper face of the sample in the radial direction. The span (L) was $28 \mathrm{~cm}$ and the cross head advanced with a speed of $10 \mathrm{~mm} / \mathrm{min}$. The modulus of rupture (MOR) was determined from the measured loaddeformation curves using the equations given below:

$$
\mathrm{MOR}=\frac{3 \mathrm{PL}}{2 \mathrm{bd}^{2}}
$$

where P: the maximum load before rupture

$\mathrm{L}$ : the length of span

b: the width of the samples

d: the thickness of the samples.

\section{RESULTS AND DISCUSSION}

\section{Heat treatment of wood color}

Increasing the temperature and treatment times caused the wood color to darken. Table 1 presents the $\mathrm{L}^{*}, \mathrm{a}^{*}, \mathrm{~b}^{*}$ and the total color difference $\Delta \mathrm{E}$ by the varying operation conditions. The lightness $\left(\mathrm{L}^{*}\right)$ for all species decreased with increasing temperatures and treatment times. The lightness $\left(\mathrm{L}^{*}\right)$ for Spruce decreased from 83.15 for the control sample to 44.56 at $230{ }^{\circ} \mathrm{C}$ and $4 \mathrm{~h}$, Yellow poplar decreased from 83.63 for the control sample to 43.58 at $230{ }^{\circ} \mathrm{C}$ and $6 \mathrm{~h}$, Pine wood decreased from 80.33 for the control sample to 40.81 at $230{ }^{\circ} \mathrm{C}$ and $6 \mathrm{~h}$. Larch decreased from 73.07 for the control sample to 38.13 at $190^{\circ} \mathrm{C}$ and $6 \mathrm{~h}$. The darkness of heat treated wood colored by degradation products from hemicelluloses and extractives participate in the color changing, especially for oxidization products such as quinones (Sundqvist, 2002; Sundqvist and Moren. 2002; Tjeerdsma et al., 1998).

The parameter $a^{*}$ for all of the four species initially increased and then decreased later. In the initial stage, the $\mathrm{a}^{*}$ increased until the temperature was $190^{\circ} \mathrm{C}$, then decreased with increasing temperatures. The $b^{*}$ increased in the initial stage, decreasing later for all four species; however, it increased only slightly up to a temperature of $170^{\circ} \mathrm{C}$ and then decreased later. The specimens initially became more red and yellow; however, as the temperatures increased, these colors were lost. The samples became redder, due to the colored degradation products formed during the hydrolysis of hemicelluloses (Sehlstedt-Persson, 2003). According to Terziev et al. (1993) and Terziev (1995), the yellowing of the samples is due to the enrichment of sugar and nitrogenous compounds in the timber surfaces during the initial, capillary phase of heat treatment. Quickly increasing temperatures lead to an increased enrichment of sugar and nitrogenous compounds toward the surface. When this carbohydrate-enriched zone is heated in the presence of amino acids working as catalysts, a degradation of the carbohydrates takes place and color degradation products are formed. Furthermore, the water storage of timber might also lead to a pronounced surface yellowing after drying

Table 1. The effect of heat treatment for different duration on color

\begin{tabular}{|c|c|c|c|c|c|c|c|c|c|c|c|c|c|c|c|c|c|}
\hline \multirow{2}{*}{$\begin{array}{l}\text { Time } \\
\text { (h) }\end{array}$} & \multirow{2}{*}{$\begin{array}{l}\text { Heat- } \\
\text { Treatment } \\
\left({ }^{\circ} \mathrm{C}\right)\end{array}$} & \multicolumn{4}{|c|}{ Spruce } & \multicolumn{4}{|c|}{ Yellow Poplar } & \multicolumn{4}{|c|}{ Pine } & \multicolumn{4}{|c|}{ Larch } \\
\hline & & $\mathrm{L}^{*}$ & $a^{*}$ & $\mathrm{~b}^{*}$ & $\Delta \mathrm{E}$ & $\mathrm{L}^{*}$ & $a^{*}$ & $b^{*}$ & $\Delta \mathrm{E}$ & $\mathrm{L}^{*}$ & $a^{*}$ & $\mathrm{~b}^{*}$ & $\Delta \mathrm{E}$ & $\mathrm{L}^{*}$ & $a^{*}$ & $b^{*}$ & $\Delta \mathrm{E}$ \\
\hline Control & & 82.99 & 4.85 & 20.79 & - & 83.33 & 0.93 & 15.46 & - & 80.16 & 4.43 & 23.02 & - & 72.85 & 11.01 & 24.41 & - \\
\hline \multirow[t]{5}{*}{2} & 150 & 78.87 & 6.12 & 23.42 & 5.79 & 78.80 & 1.83 & 19.79 & 6.14 & 75.91 & 5.51 & 25.82 & 5.04 & 67.12 & 13.33 & 26.29 & 5.83 \\
\hline & 170 & 74.98 & 7.46 & 26.29 & 9.58 & 73.41 & 4.71 & 21.42 & 13.21 & 69.47 & 7.00 & 26.22 & 10.35 & 63.79 & 14.19 & 25.08 & 9.74 \\
\hline & 190 & 58.03 & 11.64 & 26.44 & 25.96 & 58.42 & 7.03 & 21.41 & 24.99 & 52.85 & 11.15 & 25.21 & 27.45 & 46.74 & 15.03 & 21.56 & 25.29 \\
\hline & 210 & 63.59 & 10.36 & 28.05 & 20.70 & 61.45 & 6.62 & 21.89 & 23.02 & 57.09 & 10.65 & 26.78 & 24.43 & 57.33 & 13.89 & 27.69 & 17.13 \\
\hline & 230 & 49.27 & 10.53 & 22.60 & 34.86 & 48.80 & 8.72 & 20.84 & 36.52 & 46.62 & 10.67 & 21.14 & 35.19 & 42.71 & 11.22 & 21.46 & 29.51 \\
\hline \multirow[t]{5}{*}{4} & 150 & 77.57 & 6.84 & 23.80 & 6.72 & 75.47 & 2.57 & 19.37 & 8.26 & 72.93 & 6.27 & 25.92 & 6.79 & 65.65 & 13.76 & 25.70 & 6.86 \\
\hline & 170 & 70.07 & 8.59 & 26.61 & 13.70 & 72.66 & 4.16 & 20.89 & 13.91 & 67.31 & 7.62 & 27.51 & 13.65 & 57.73 & 15.02 & 25.50 & 14.79 \\
\hline & 190 & 51.97 & 10.95 & 23.81 & 31.70 & 54.13 & 8.86 & 22.55 & 31.88 & 48.37 & 11.78 & 23.88 & 32.79 & 43.32 & 13.80 & 19.29 & 30.74 \\
\hline & 210 & 54.27 & 10.39 & 24.27 & 31.01 & 50.69 & 9.02 & 20.55 & 34.20 & 50.50 & 10.51 & 23.27 & 31.19 & 48.83 & 12.85 & 25.30 & 23.75 \\
\hline & 230 & 44.56 & 10.66 & 20.20 & 38.82 & 48.20 & 8.59 & 16.89 & 34.57 & 43.91 & 10.22 & 19.36 & 39.16 & 40.84 & 10.20 & 19.39 & 34.23 \\
\hline \multirow[t]{5}{*}{6} & 150 & 74.93 & 7.79 & 24.09 & 9.36 & 73.45 & 3.30 & 16.98 & 9.51 & 71.03 & 7.40 & 26.13 & 8.30 & 65.53 & 13.43 & 24.93 & 9.32 \\
\hline & 170 & 65.61 & 10.13 & 27.60 & 18.75 & 66.35 & 3.88 & 21.22 & 16.37 & 63.20 & 9.39 & 28.25 & 17.13 & 55.04 & 15.39 & 23.90 & 18.13 \\
\hline & 190 & 47.26 & 11.61 & 21.95 & 37.00 & 47.65 & 9.86 & 21.15 & 36.78 & 45.13 & 11.72 & 21.46 & 36.23 & 38.13 & 12.29 & 15.54 & 35.81 \\
\hline & 210 & 53.53 & 11.53 & 24.70 & 30.49 & 50.56 & 8.80 & 20.93 & 32.47 & 48.76 & 11.58 & 23.01 & 33.55 & 47.21 & 13.95 & 24.06 & 24.84 \\
\hline & 230 & 44.64 & 10.09 & 20.06 & 38.67 & 43.58 & 8.48 & 18.57 & 40.92 & 40.81 & 9.84 & 16.71 & 33.55 & 38.44 & 8.18 & 16.79 & 36.27 \\
\hline
\end{tabular}

Note : $\mathrm{L}^{*}$ : lightness varies from black to white; $\mathrm{a}^{*}$ : the colors vary from green to red; $\mathrm{b}^{*}$ : the colors vary from blue to yellow; $\Delta \mathrm{E}$ : the total color difference. 


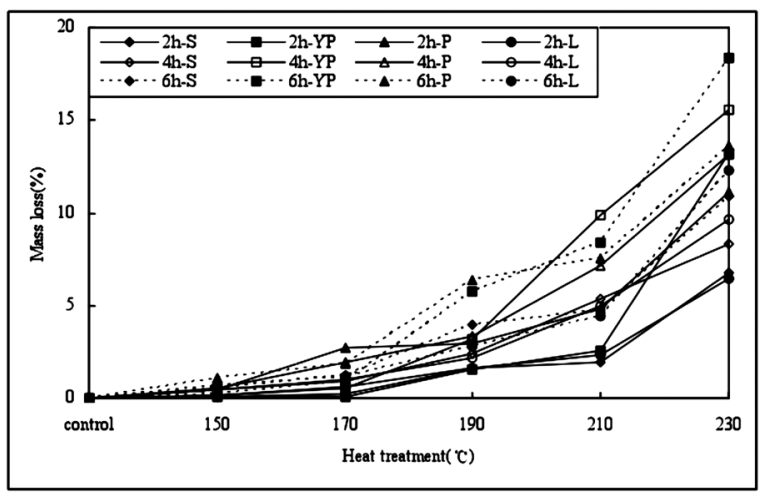

Fig. 2. Changes in mass loss of all samples due to heat treatment.

(Theander et al., 1993).

The total color difference $\Delta \mathrm{E}$ increased with the temperature and treatment times. The $\mathrm{L}^{*}$ decreased with the increasing temperatures, and the $\mathrm{a}^{*}$ and $\mathrm{b}^{*}$ initially increased and later decreased, finally losing their color. These results, therefore, correspond to the changes in $\Delta \mathrm{E}$, dominated by $\mathrm{L}^{*}$ and less effected by $\mathrm{a}^{*}$ and $\mathrm{b}^{*}$. The color changes resulting from hemicelluloses degradation might be due to hydrolysis from a reaction and extractives dissolution, oxidization, decomposition or migration (Sundqvist, 2002; Sundqvist and Moren. 2002; C. H .S. Del Menezzi et al., 2009; Carrier et al., 2002; Varga and Van der Zee, 2008).

\section{Mass loss}

Table 2. Equilibrium moisture content (EMC) and EMC changes of all samples at $40{ }^{\circ} \mathrm{C}$, and $75 \%$ and $90 \%$ relative humidity

\begin{tabular}{|c|c|c|c|c|c|c|c|c|c|c|c|c|c|c|c|c|c|}
\hline \multirow{3}{*}{$\begin{array}{l}\text { Time } \\
\text { (h) }\end{array}$} & \multirow{3}{*}{$\begin{array}{c}\text { Heat- } \\
\text { Treatment } \\
\left({ }^{\circ} \mathrm{C}\right)\end{array}$} & \multicolumn{4}{|c|}{ Spruce } & \multicolumn{4}{|c|}{ Yellow Poplar } & \multicolumn{4}{|c|}{ Pine } & \multicolumn{4}{|c|}{ Larch } \\
\hline & & \multicolumn{2}{|c|}{$75 \%-\mathrm{RH}$} & \multicolumn{2}{|c|}{$90 \%-\mathrm{RH}$} & \multicolumn{2}{|c|}{$75 \%-\mathrm{RH}$} & \multicolumn{2}{|c|}{$90 \%-\mathrm{RH}$} & \multicolumn{2}{|c|}{$75 \%-\mathrm{RH}$} & \multicolumn{2}{|c|}{$90 \%-\mathrm{RH}$} & \multicolumn{2}{|c|}{$75 \%-\mathrm{RH}$} & \multicolumn{2}{|c|}{$90 \%-\mathrm{RH}$} \\
\hline & & EMC & $\Delta \mathrm{EMC}$ & EMC & $\Delta \mathrm{EMC}$ & $\mathrm{EMC}$ & $\Delta \mathrm{EMC}$ & EMC & $\Delta \mathrm{EMC}$ & EMC & $\Delta \mathrm{EMC}$ & EMC & $\Delta \mathrm{EMC}$ & EMC & $\Delta \mathrm{EMC}$ & EMC & $\Delta \mathrm{EMC}$ \\
\hline 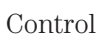 & & 12.18 & - & 16.73 & - & 53 & - & 16.15 & - & 10.52 & - & 15.65 & - & .80 & - & 16.48 & - \\
\hline \multirow[t]{5}{*}{2} & 150 & 11.08 & 9.02 & 16.26 & 2.80 & 10.97 & 4.82 & 15.69 & 2.81 & 10.78 & 1.30 & 15.71 & -0.41 & 10.81 & 8.43 & 15.44 & 6.31 \\
\hline & 170 & 10.42 & 14.44 & 14.78 & 2. & 10.00 & 13.27 & 14.98 & 7.20 & 9.74 & 10.86 & 14.60 & 6.71 & 10.28 & 12.93 & 15.02 & 8.90 \\
\hline & 190 & 9.94 & 18.42 & 13.45 & 19.64 & 9.19 & 20.28 & 13.20 & 18.23 & 9.82 & 10.08 & 13.55 & 13.41 & 10.00 & 15.26 & 14.14 & 14.20 \\
\hline & 210 & 8.22 & 32.51 & 11.79 & 29.56 & 6.85 & 40.55 & 10.96 & 32.11 & 7.86 & 28.07 & 11.51 & 26.48 & 8.22 & 30.35 & 11.82 & 28.29 \\
\hline & 230 & 6.10 & 49.90 & 9.46 & 43.46 & 5.22 & 54.68 & 8.18 & 49.31 & 6.42 & 41.18 & 9.37 & 40.14 & 6.97 & 40.92 & 10.58 & 35.84 \\
\hline \multirow[t]{5}{*}{4} & 150 & 12.51 & -2.69 & 16.15 & 3.49 & 10.78 & 6.47 & 15.82 & 2.04 & 10.96 & -0.34 & 15.54 & 0.70 & 11.10 & 5.91 & 15.92 & 3.41 \\
\hline & 170 & 12.01 & 1.36 & 15.47 & 7.55 & 10.26 & 10.97 & 14.39 & 10.88 & 10.12 & 7.36 & 14.51 & 7.30 & 10.45 & 11.46 & 14.88 & 9.72 \\
\hline & 190 & 7.80 & 35.95 & 11.72 & 29.97 & 7.17 & 37.84 & 11.02 & 31.71 & 8.04 & 26.35 & 12.41 & 20.70 & 8.36 & 29.20 & 12.55 & 23.87 \\
\hline & 210 & 8.59 & 29.45 & 11.33 & 32.27 & 6.97 & 39.57 & 9.76 & 39.57 & 8.65 & 20.81 & 11.27 & 27.97 & 8.22 & 30.34 & 11.35 & 31.14 \\
\hline & 230 & 6.31 & 48.22 & 9.00 & 46.22 & 5.38 & 53.33 & 7.90 & 51.06 & 6.25 & 42.74 & 9.68 & 38.13 & 6.13 & 48.06 & 8.99 & 45.47 \\
\hline \multirow[t]{5}{*}{6} & 150 & 12.61 & -3.52 & 15.88 & 5.11 & 10.83 & 6.03 & 15.46 & 4.24 & 10.94 & -0.16 & 15.39 & 1.62 & 11.00 & 6.82 & 15.91 & 3.50 \\
\hline & 170 & 10.72 & 11.95 & 14.52 & 13.20 & 10.03 & 13.04 & 14.36 & 11.08 & 10.27 & 5.94 & 14.55 & 7.02 & 10.29 & 12.80 & 12.95 & 21.45 \\
\hline & 190 & 9.14 & 24.99 & 12.25 & 26.80 & 7.86 & 31.78 & 11.15 & 30.95 & 8.85 & 19.00 & 11.97 & 23.50 & 9.48 & 19.70 & 13.30 & 19.31 \\
\hline & 210 & 8.60 & 29.36 & 11.19 & 33.12 & 7.24 & 37.22 & 10.10 & 37.46 & 8.57 & 21.49 & 11.27 & 28.00 & 8.56 & 27.44 & 12.01 & 27.13 \\
\hline & 230 & 5.88 & 51.73 & 9.06 & 45.88 & 5.17 & 55.14 & 8.05 & 50.11 & 5.53 & 49.33 & 8.67 & 44.58 & 5.44 & 53.88 & 7.90 & 52.05 \\
\hline
\end{tabular}

Mass loss of wood is one of the most important features in heat treatment and is commonly seen as an indication of degradation. Esteves et al. (2007) reported that the mass loss with heat treatment depends on the wood species, heating temperature and treatment time. Mass loss caused by hemicellulose degradation and extractives migration substances in the cell wall under the high temperature (Sundqvist and Moren, 2002).

Fig. 2 depicts the mass losses of the Spruce, Yellow poplar, Pine and Larch samples after the heat treatment. For Larch, the mass loss varied between $0.12 \%$ at $150{ }^{\circ} \mathrm{C}$ for $2 \mathrm{~h}$ and $12.28 \%$ at $230{ }^{\circ} \mathrm{C}$ for $6 \mathrm{~h}$. For Pine, the mass loss varied between $0.44 \%$ at $150{ }^{\circ} \mathrm{C}$ for $2 \mathrm{~h}$ and $13.61 \%$ at $230{ }^{\circ} \mathrm{C}$ for $6 \mathrm{~h}$. Spruce showed a mass loss which varied between $0.04 \%$ at $150{ }^{\circ} \mathrm{C}$ for $2 \mathrm{~h}$ and $10.92 \%$ at $230{ }^{\circ} \mathrm{C}$ for 6 h. For Yellow poplar, the mass loss was between $0.44 \%$ at $150{ }^{\circ} \mathrm{C}$ for $2 \mathrm{~h}$ and $13.61 \%$ at $230{ }^{\circ} \mathrm{C}$ for $6 \mathrm{~h}$. Despite some differences between the species, their growth correlating to variations in the temperatures and times were similar. In general, the mass loss increased with increasing temperatures and times for all of the wood species; however, they differed in terms of the species and kinetics of the heat treatment induced mass loss. No significant mass loss was found for any of the four species tested at 150 and $170{ }^{\circ} \mathrm{C}$, although the mass loss for Pine was higher than for the others at the same conditions. This may be due to high resin content of Pine. Conversely, at $190{ }^{\circ} \mathrm{C}$, the mass loss of all of the species changed drastically, both in terms of treatment temperature and time. Thus, the chemical degradation began at approximately $190^{\circ} \mathrm{C}$, which is similar to the degradation of polyoses which start at about $200^{\circ} \mathrm{C}$, as presented by 
Byrne and Nagle (1997). At 210 and $230{ }^{\circ} \mathrm{C}$, the mass loss of Yellow poplar was much higher than for the other three species, due to the chemical structure differences between hardwood and softwood. We found that the change in mass loss due to temperature was greater than for the treatment time. Thus, temperature is a more important factor than time in terms of determining mass loss, mirroring the results of Mazela et al. (2004).

\section{Equilibrium Moisture Content (EMC)}

Table 2 represents the equilibrium moisture content (EMC) and EMC changes for all of the samples at $40{ }^{\circ} \mathrm{C}$, and $75 \%$ and $90 \%$ relative humidity. The EMC of heat treated wood decreased with the temperature increase. For all of the four species, the lowest values of the EMC appeared at $230{ }^{\circ} \mathrm{C}$. At $75 \%$ relative humidity, the lowest EMC value was 5.44\% for Larch, 5.53\% for Pine, 5.88\% for Spruce and $5.17 \%$ for Yellow poplar at a temperature of $230{ }^{\circ} \mathrm{C}$ for $6 \mathrm{~h}$. At the $90 \%$ relative humidity, the lowest EMC value was $9.00 \%$ for Spruce and $7.90 \%$ for Yellow poplar at a temperature of $230{ }^{\circ} \mathrm{C}$ for $4 \mathrm{~h}$ and $7.90 \%$ for Larch and $8.67 \%$ for Pine at a temperature of $230{ }^{\circ} \mathrm{C}$ for $6 \mathrm{~h}$. According to Jamsa and Viitanniemi (2001), the equilibrium moisture content decreases because less water is absorbed by the cell walls after the heat treatment as a result of chemical changes, with a decrease in the hydroxyl groups. Other research has argued that the enhanced inaccessibility is also significant (Bhuiyan and Hirai, 2005; Boonstra and Tjeerdsma, 2006). Morever, it has been suggested that the polycondensation reactions in lignin result in further cross-linking that might also contribute to the decrease of equilibrium moisture con-

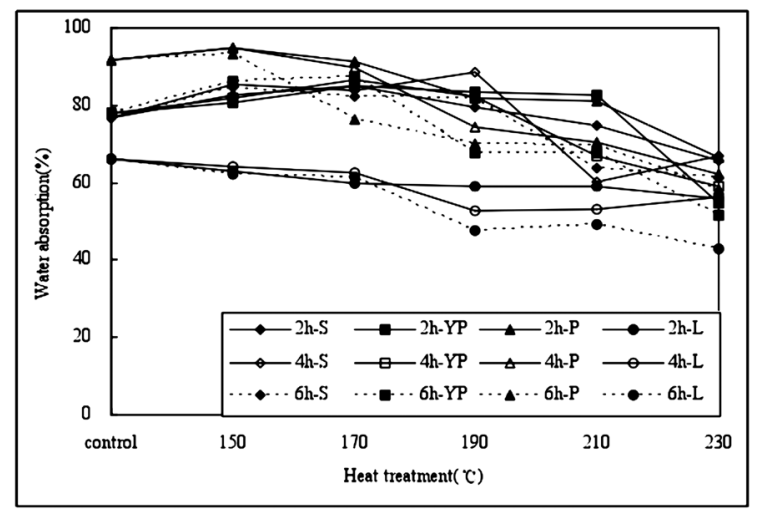

Note : S - Spruce; YP - Yellow poplar; P- Pine; L - Larch.

Fig. 3. Changes in water absorption of all samples due to heat treatment.

tent (Tjeerdsma and Miliz, 2005; Evteves et al., 2008).

As seen in Table 2, the decreasing magnitude of the heat treatment was greater with increasing treatment temperatures. No significant EMC change was found in any of the four species for treatment times at the same temperature. Thus, treatment temperature has a greater influence on EMC than treatment time.

The maximum EMC losses occured at $230{ }^{\circ} \mathrm{C}$ for $6 \mathrm{~h}$ for Pine, Larch, Spruce and Yellow Poplar, with loss values of $53.88 \%, 49.33 \%, 51.93 \%$ and $55.14 \%$ respectively. The maximum EMC losses were obtained at a treatment temperature of $230{ }^{\circ} \mathrm{C}$. Previous research has shown similar results, arguing that the heat treatment process leads to a reduction in the EMC (Metsa-Kortelainen et al., 2006). When wood is treated at $230^{\circ} \mathrm{C}$, the EMC can

Table 3. Cross-sectional, longitudinal and volumetric swelling of heat treated and untreated samples

\begin{tabular}{|c|c|c|c|c|c|c|c|c|c|c|c|c|c|}
\hline \multirow{2}{*}{$\begin{array}{l}\text { Heat- } \\
\text { Treatment } \\
\left({ }^{\circ} \mathrm{C}\right)\end{array}$} & \multirow{2}{*}{$\begin{array}{l}\text { Time } \\
\text { (h) }\end{array}$} & \multicolumn{3}{|c|}{ Pine } & \multicolumn{3}{|c|}{ Larch } & \multicolumn{3}{|c|}{ Spruce } & \multicolumn{3}{|c|}{ Yellow Poplar } \\
\hline & & C & $\mathrm{L}$ & $\mathrm{V}$ & C & $\mathrm{L}$ & $\mathrm{V}$ & C & $\mathrm{L}$ & $\mathrm{V}$ & C & $\mathrm{L}$ & $\mathrm{V}$ \\
\hline Control & & 12.29 & 0.53 & 12.88 & 7.18 & 0.51 & 7.72 & 9.09 & 0.31 & 9.43 & 11.12 & 0.64 & 11.83 \\
\hline \multirow[t]{3}{*}{150} & 2 & 12.90 & 0.43 & 13.38 & 7.86 & 0.69 & 8.60 & 10.47 & 0.40 & 10.91 & 12.40 & 0.83 & 13.34 \\
\hline & 4 & 13.60 & 0.51 & 14.18 & 8.83 & 0.99 & 9.92 & 10.41 & 0.15 & 10.57 & 12.27 & 0.45 & 12.77 \\
\hline & 6 & 13.85 & 0.35 & 14.24 & 7.95 & 0.54 & 8.53 & 10.57 & 0.29 & 10.89 & 13.80 & 0.69 & 14.58 \\
\hline \multirow[t]{3}{*}{170} & 2 & 12.61 & 0.35 & 13.00 & 8.59 & 0.54 & 9.17 & 10.21 & 0.34 & 10.58 & 11.55 & 0.22 & 11.80 \\
\hline & 4 & 11.98 & 0.20 & 12.21 & 8.30 & 0.28 & 8.61 & 9.87 & 0.27 & 10.16 & 10.46 & 0.23 & 10.71 \\
\hline & 6 & 11.98 & 0.13 & 12.13 & 7.15 & 0.30 & 7.48 & 6.80 & 0.27 & 7.08 & 9.91 & 0.24 & 10.17 \\
\hline \multirow[t]{3}{*}{190} & 2 & 11.22 & 0.88 & 12.19 & 8.43 & 0.68 & 9.17 & 8.87 & 0.78 & 9.73 & 10.24 & 0.63 & 10.93 \\
\hline & 4 & 10.02 & 0.22 & 10.27 & 7.29 & 0.27 & 7.58 & 7.50 & 0.13 & 7.64 & 9.11 & 0.36 & 9.50 \\
\hline & 6 & 9.22 & 0.16 & 9.39 & 6.49 & 0.18 & 6.68 & 6.86 & 0.07 & 6.94 & 7.21 & 0.08 & 7.30 \\
\hline \multirow[t]{3}{*}{210} & 2 & 9.67 & 0.36 & 10.06 & 7.00 & 0.43 & 7.46 & 7.72 & 0.13 & 7.86 & 9.26 & 0.25 & 9.53 \\
\hline & 4 & 7.19 & 0.27 & 7.48 & 5.09 & 0.30 & 5.40 & 6.24 & 0.29 & 6.55 & 6.59 & 0.18 & 6.78 \\
\hline & 6 & 8.49 & 0.37 & 8.90 & 5.50 & 0.23 & 5.75 & 7.18 & 0.42 & 7.63 & 6.57 & 0.08 & 6.57 \\
\hline \multirow[t]{3}{*}{230} & 2 & 6.79 & 0.34 & 7.14 & 5.47 & 0.19 & 5.67 & 5.90 & 0.39 & 6.32 & 6.12 & 0.53 & 6.69 \\
\hline & 4 & 7.10 & 0.29 & 7.42 & 4.74 & 0.77 & 5.54 & 6.50 & 0.78 & 7.33 & 6.73 & 0.92 & 7.72 \\
\hline & 6 & 5.07 & 0.12 & 5.20 & 3.29 & 0.13 & 3.43 & 4.06 & 0.17 & 4.24 & 4.67 & 0.15 & 4.82 \\
\hline
\end{tabular}

Note : C-cross sectional swelling; L-longitudinal swelling; V-volumetric swelling 
be reduced by approximately 40 50\% compared to untreated wood.

\section{Water absorption and Swelling}

The change in water absorption is primarily caused by the thermal degradation of hemicellulose. Theoretically, the hygroscopic $\mathrm{OH}$ groups of hemicellulose have the most significant effect on the hygroscopicity of wood. As a result of the reduction in the number of hydroxyl groups, the water absorption and swelling ratio of heat treated woods decrease.

The water absorption contents of the specimens after the soaking/oven drying tests are shown in Fig. 3. Each column represents the average of ten replications for each of the treatment groups. For the Pine, Spruce and Yellow poplar, the water absorption initially increased and the water absorption decreased with increasing temperature and treatment times. For Larch, the water absorption decreased with increasing temperatures and changed slightly. The smallest water sorption compared to the untreated samples appeared at $230{ }^{\circ} \mathrm{C}$ for $6 \mathrm{~h}$, with water absorption decreasing 23.19\% for Larch, 33.48\% for Pine, $15.57 \%$ for Spruce and $26.49 \%$ for Yellow poplar. Thus, the chemical degradation started when the temperature exceeded $150^{\circ} \mathrm{C}$ and the degradation rate increased with the temperature and time.

Furthermore, the cross-sectional and volumetric average swellings increased when the specimens were treated at $150{ }^{\circ} \mathrm{C}$. The decreasing of swelling is thus similar to the water absorption. The longitudinal swelling changed very little, with the smallest longitudinal swelling percentage occuring at $230{ }^{\circ} \mathrm{C}$ for $6 \mathrm{~h}$ for all of the species. The micelle space acquires water molecules easier than the longitudinal direction of the micelle (Jung H. S., 1986). The volumetric swelling was greater than the cross-sectional and longitudinal swelling, with the value was nearly equal to the sum of the cross-sectional and longitudinal swelling values. The decrease in swelling for heat treated wood is predominantly caused by the decrease in the wood's hygroscopicity due to the chemical changes at high temperatures. Shuichi Doi et al. (2005) reported that the swelling is the result of the formation of polymers from sugars that are less hygroscopic than the hemicelluloses from their derivation. Tjeerdsma et al. (1998a) noted that one of the probable reasons for a decreasing of swelling is the loss of methyl radicals for some of the guaiacylic and siringlic units of lignin and that those reactions lead to an increase in phenolic groups. These chemical changes lead to higher lignin reactivity with the formation of several cross-links, contributing to decreases in swelling. With the increase of cross-linking, the molecule becomes less elastic and the cellulose microfibrils have less expansion and water absorption possibilities; thus, the decrease in equilibrium moisture and swelling.

\section{Bending strength}

One of the main disadvantages of heat treated wood is the decrease in mechanical strength, making this wood unsuitable for most structural applications. The comparison between the control and treated wood in MOR are presented in Table 5. The MOR changes depended on the wood species and the heat treatment conditions. For Spruce and Yellow poplar, the MOR values decreased

Table 4. MOR and MOR changes of all samples due to heat treatment

\begin{tabular}{|c|c|c|c|c|c|c|c|c|c|}
\hline \multirow{2}{*}{$\begin{array}{l}\text { Time } \\
\text { (h) }\end{array}$} & \multirow{2}{*}{$\begin{array}{c}\text { Heat- } \\
\text { Treatment } \\
\left({ }^{\circ} \mathrm{C}\right)\end{array}$} & \multicolumn{2}{|c|}{ Spruce } & \multicolumn{2}{|c|}{ Yellow Poplar } & \multicolumn{2}{|c|}{ Pine } & \multicolumn{2}{|c|}{ Larch } \\
\hline & & $\operatorname{MOR}(\mathrm{N} / \mathrm{mm})$ & $\Delta \mathrm{MOR}(\%)$ & $\mathrm{MOR}(\mathrm{N} / \mathrm{mm})$ & $\Delta \mathrm{MOR}(\%)$ & $\operatorname{MOR}(\mathrm{N} / \mathrm{mm})$ & $\triangle \mathrm{MOR}(\%)$ & $\operatorname{MOR}(\mathrm{N} / \mathrm{mm})$ & $\triangle \mathrm{MOR}(\%)$ \\
\hline Control & & 9.95 & - & 9.66 & - & 10.01 & - & 10.13 & - \\
\hline \multirow[t]{5}{*}{2} & 150 & 6.32 & 36.53 & 6.45 & 33.22 & 10.53 & -5.29 & 11.28 & -11.38 \\
\hline & 170 & 7.30 & 26.65 & 8.66 & 10.38 & 9.80 & 2.01 & 9.74 & 3.86 \\
\hline & 190 & 6.92 & 30.43 & 7.86 & 18.64 & 7.64 & 23.66 & 8.65 & 14.65 \\
\hline & 210 & 7.57 & 23.90 & 7.93 & 17.86 & 9.22 & 7.84 & 8.56 & 15.50 \\
\hline & 230 & 6.74 & 32.30 & 7.43 & 23.04 & 6.98 & 30.27 & 6.32 & 37.65 \\
\hline \multirow[t]{5}{*}{4} & 150 & 7.76 & 22.06 & 8.40 & 13.01 & 10.52 & -5.17 & 9.59 & 5.34 \\
\hline & 170 & 7.08 & 28.85 & 7.92 & 17.96 & 9.92 & 0.86 & 8.42 & 16.85 \\
\hline & 190 & 5.52 & 44.49 & 6.61 & 31.52 & 6.52 & 34.84 & 6.61 & 34.71 \\
\hline & 210 & 6.82 & 31.42 & 7.31 & 24.36 & 7.02 & 29.85 & 7.73 & 23.68 \\
\hline & 230 & 6.73 & 32.38 & 6.41 & 33.62 & 5.87 & 41.32 & 5.79 & 42.84 \\
\hline \multirow[t]{5}{*}{6} & 150 & 7.71 & 22.51 & 9.02 & 6.64 & 9.12 & 8.86 & 10.06 & 0.67 \\
\hline & 170 & 7.07 & 28.97 & 7.87 & 18.55 & 9.20 & 8.00 & 8.94 & 11.76 \\
\hline & 190 & 6.71 & 32.56 & 6.70 & 30.58 & 6.30 & 37.00 & 6.95 & 31.35 \\
\hline & 210 & 6.51 & 34.54 & 7.33 & 24.14 & 7.62 & 23.83 & 7.88 & 22.19 \\
\hline & 230 & 6.62 & 33.47 & 8.03 & 16.85 & 7.00 & 30.05 & 4.73 & 53.27 \\
\hline
\end{tabular}


Table 5. Color variables significantly included in the models as predictors to estimate physical properties of heat treated wood using multiple stepwise regression

\begin{tabular}{|c|c|c|c|c|c|c|}
\hline Property & Species & $\begin{array}{c}\text { Relative } \\
\text { humidity }\end{array}$ & Color variables & $\mathrm{R}^{2}$ & Equation & n \\
\hline \multirow{9}{*}{ Mass loss } & \multirow{2}{*}{ Spruce } & - & $\mathrm{L}^{*}$ & 0.686 & $\mathrm{y}=16.625-0.220 \mathrm{~L}^{*}$ & 150 \\
\hline & & - & $\mathrm{L}^{*}$ and $\mathrm{a}^{*}$ & 0.813 & $\mathrm{y}=34.572-0.352 \mathrm{~L}^{*}-1.027 \mathrm{a}^{*}$ & 150 \\
\hline & \multirow{2}{*}{ Yellow poplar } & - & $\mathrm{L}^{*}$ & 0.674 & $\mathrm{y}=28.771-0.392 \mathrm{~L}^{*}$ & 150 \\
\hline & & - & $\mathrm{L}^{*}$ and $\mathrm{b}^{*}$ & 0.713 & $\mathrm{y}=38.196-0.382 \mathrm{~L}^{*}-0.487 \mathrm{~b} *$ & 150 \\
\hline & \multirow{2}{*}{ Pine } & - & $\mathrm{L}^{*}$ & 0.558 & $\mathrm{y}=22.766-0.310 \mathrm{~L}^{*}$ & 150 \\
\hline & & - & $\mathrm{L}^{*}$ and $\mathrm{a}^{*}$ & 0.615 & $\mathrm{y}=40.340-0.457 \mathrm{~L}^{*}-0.975 \mathrm{a}^{*}$ & 150 \\
\hline & \multirow{3}{*}{ Larch } & - & $a^{*}$ & 0.580 & $\mathrm{y}=19.628-1.239 \mathrm{a}^{*}$ & 150 \\
\hline & & - & $\mathrm{L}^{*}$ and $\mathrm{a}^{*}$ & 0.737 & $\mathrm{y}=23.157-0.921 \mathrm{a}^{*}-0.148 \mathrm{~L}^{*}$ & 150 \\
\hline & & - & $\mathrm{L}^{*}, \mathrm{a}^{*}$ and $\mathrm{b}^{*}$ & 0.811 & $\mathrm{y}=21.826-1.139 \mathrm{a}^{*}-0.255 \mathrm{~L}^{*}-0.426 \mathrm{~b}^{*}$ & 150 \\
\hline \multirow{23}{*}{$\mathrm{EMC}$} & \multirow{6}{*}{ Spruce } & \multirow{3}{*}{$75 \%$} & $\mathrm{~L}^{*}$ & 0.729 & $\mathrm{y}=0.62+0.153 \mathrm{~L}^{*}$ & 150 \\
\hline & & & $\mathrm{L}^{*}$ and $\mathrm{a}^{*}$ & 0.765 & $\mathrm{y}=0.201 \mathrm{~L}^{*}+0.372 \mathrm{a}^{*}-6.433$ & 150 \\
\hline & & & $\mathrm{L}^{*}, \mathrm{a}^{*}$ and $\mathrm{b}^{*}$ & 0.803 & $\mathrm{y}=0.310 \mathrm{~L}^{*}+0.964 \mathrm{a}^{*}-0.316 \mathrm{~b} *-11.108$ & 150 \\
\hline & & \multirow{3}{*}{$90 \%$} & $\mathrm{~L}^{*}$ & 0.823 & $\mathrm{y}=1.476+0.187 \mathrm{~L}^{*}$ & 150 \\
\hline & & & $\mathrm{L}^{*}$ and $\mathrm{a}^{*}$ & 0.841 & $\mathrm{y}=0.225 \mathrm{~L}^{*}+0.296 \mathrm{a} *-3.695$ & 150 \\
\hline & & & $\mathrm{L}^{*}, \mathrm{a}^{*}$ and $\mathrm{b}^{*}$ & 0.863 & $\mathrm{y}=0.321 \mathrm{~L}^{*}+0.814 \mathrm{a}^{*}-0.276 \mathrm{~b} *-7.784$ & 150 \\
\hline & \multirow{6}{*}{ Yellow poplar } & \multirow{3}{*}{$75 \%$} & $\mathrm{~L}^{*}$ & 0.776 & $\mathrm{y}=0.144 \mathrm{~L} *-0.354$ & 150 \\
\hline & & & $\mathrm{L}^{*}$ and $\mathrm{a}^{*}$ & 0.789 & $\mathrm{y}=2.294+0.116 \mathrm{~L}^{*}-0.150 \mathrm{a}^{*}$ & 150 \\
\hline & & & $\mathrm{L}^{*}, \mathrm{a}^{*}$ and $\mathrm{b}^{*}$ & 0.798 & $\mathrm{y}=2.030+0.96 \mathrm{~L} *-0.246 \mathrm{a}^{*}+0.101 \mathrm{~b} *$ & 150 \\
\hline & & \multirow{3}{*}{$90 \%$} & $\mathrm{~L}^{*}$ & 0.824 & $\mathrm{y}=0.202 \mathrm{~L} *-0.027$ & 150 \\
\hline & & & $\mathrm{L}^{*}$ and $\mathrm{a}^{*}$ & 0.835 & $\mathrm{y}=3.307+0.167 \mathrm{~L}^{*}-0.189 \mathrm{a}^{*}$ & 150 \\
\hline & & & $\mathrm{L}^{*}, \mathrm{a}^{*}$ and $\mathrm{b}^{*}$ & 0.847 & $\mathrm{y}=2.894+0.136 \mathrm{~L}^{*}-0.340 \mathrm{a}^{*}+0.159 \mathrm{~b} *$ & 150 \\
\hline & \multirow{5}{*}{ Pine } & \multirow{2}{*}{$75 \%$} & $\mathrm{~L}^{*}$ & 0.477 & $\mathrm{y}=2.049+0.120 \mathrm{~L}^{*}$ & 150 \\
\hline & & & $\mathrm{L}^{*}$ and $\mathrm{A}^{*}$ & 0.500 & $\mathrm{y}=0.158 \mathrm{~L}^{*}+0.257 \mathrm{~A}^{*}-2.578$ & 150 \\
\hline & & \multirow{3}{*}{$90 \%$} & $\mathrm{~L}^{*}$ & 0.756 & $\mathrm{y}=2.876+0.172 \mathrm{~L}^{*}$ & 150 \\
\hline & & & $\mathrm{L}^{*}$ and $\mathrm{a}^{*}$ & 0.769 & $\mathrm{y}=0.205 \mathrm{~L}^{*}+0.219 \mathrm{a}^{*}-1.076$ & 150 \\
\hline & & & $\mathrm{L}^{*}, \mathrm{a}^{*}$ and $\mathrm{b}^{*}$ & 0.777 & $\mathrm{y}=0.287 \mathrm{~L}^{*}+0.509 \mathrm{a}^{*}-0.164 \mathrm{~b} *-4.535$ & 150 \\
\hline & \multirow{6}{*}{ Larch } & \multirow{3}{*}{$75 \%$} & $\mathrm{~L}^{*}$ & 0.524 & $\mathrm{y}=2.762+0.121 \mathrm{~L}^{*}$ & 149 \\
\hline & & & $\mathrm{L}^{*}$ and $\mathrm{a}^{*}$ & 0.692 & $\mathrm{y}=0.088 \mathrm{~L}^{*}+0.374 \mathrm{a}^{*}-0.444$ & 149 \\
\hline & & & $\mathrm{L}^{*}, \mathrm{a}^{*}$ and $\mathrm{b}^{*}$ & 0.829 & $\mathrm{y}=0.467+0.160 \mathrm{~L}^{*}+0.518 \mathrm{a}^{*}-0.285 \mathrm{~b}$ & 149 \\
\hline & & \multirow{3}{*}{$90 \%$} & $\mathrm{~L}^{*}$ & 0.378 & $\mathrm{y}=4.326+0.165 \mathrm{~L}^{*}$ & 149 \\
\hline & & & $\mathrm{L}^{*}$ and $\mathrm{a}^{*}$ & 0.488 & $\mathrm{y}=0.162+0.122 \mathrm{~L}^{*}+0.485 \mathrm{a}^{*}$ & 149 \\
\hline & & & $\mathrm{L}^{*}, \mathrm{a}^{*}$ and $\mathrm{b}^{*}$ & 0.605 & $\mathrm{y}=1.511+0.228 \mathrm{~L}^{*}+0.699 \mathrm{a}^{*}-0.423 \mathrm{~b}^{*}$ & 149 \\
\hline \multirow{9}{*}{ Swelling } & Spruce & - & $\mathrm{L}^{*}$ & 0.514 & $\mathrm{y}=0.082+0.135 \mathrm{~L} *$ & 150 \\
\hline & \multirow{3}{*}{ Yellow poplar } & - & $\mathrm{L}^{*}$ & 0.639 & $\mathrm{y}=0.188 \mathrm{~L}^{*}-1.692$ & 150 \\
\hline & & - & $\mathrm{L}^{*}$ and $\mathrm{a}^{*}$ & 0.652 & $\mathrm{y}=2.136+0.147 \mathrm{~L} *-0.217 \mathrm{a}^{*}$ & 150 \\
\hline & & - & $\mathrm{L}^{*}, \mathrm{a}^{*}$ and $\mathrm{b}^{*}$ & 0.663 & $\mathrm{y}=1.713+0.115 \mathrm{~L}^{*}-0.371 \mathrm{a}^{*}+0.163 \mathrm{~b}^{*}$ & 150 \\
\hline & \multirow{2}{*}{ Pine } & - & $\mathrm{L}^{*}$ & 0.592 & $\mathrm{y}=0.205 \mathrm{~L}^{*}-1.183$ & 149 \\
\hline & & - & $\mathrm{L}^{*}$ and $\mathrm{a}^{*}$ & 0.609 & $\mathrm{y}=0.257 \mathrm{~L}^{*}+0.345 \mathrm{a}^{*}-7.417$ & 149 \\
\hline & \multirow{3}{*}{ Larch } & - & $\mathrm{L}^{*}$ & 0.331 & $\mathrm{y}=0.822+0.124 \mathrm{~L}^{*}$ & 150 \\
\hline & & - & $\mathrm{L}^{*}$ and $\mathrm{a}^{*}$ & 0.407 & $\mathrm{y}=0.095 \mathrm{~L}^{*}+0.323 \mathrm{a} *-1.873$ & 150 \\
\hline & & - & $L^{*}, a^{*}$ and $b^{*}$ & 0.463 & $\mathrm{y}=0.154 \mathrm{~L}^{*}+0.444 \mathrm{a}^{*}-0.237 \mathrm{~b} *-1.134$ & 150 \\
\hline & Spruce & - & $\mathrm{L}^{*}$ & 0.074 & $\mathrm{y}=0.024 \mathrm{~L}^{*}+5.405$ & 146 \\
\hline & Yellow poplar & - & $\mathrm{L}^{*}$ & 0.043 & $\mathrm{y}=6.235+0.022 \mathrm{~L}^{*}$ & 150 \\
\hline MOR & Pine & - & $L^{*}$ & 0.405 & $\mathrm{y}=1.436+0.119 \mathrm{~L}^{*}$ & 150 \\
\hline & & - & $\mathrm{L}^{*}$ & 0.443 & $\mathrm{y}=0.607+0.144 \mathrm{~L}^{*}$ & 150 \\
\hline & Larch & - & $\mathrm{L}^{*}$ and $\mathrm{a}^{*}$ & 0.519 & $\mathrm{y}=0.114 \mathrm{~L}^{*}+0.323 \mathrm{a}^{*}-2.094$ & 150 \\
\hline
\end{tabular}

Note : The model is of the form: $\mathrm{y}=\mathrm{b} 0+\sum \mathrm{bi} \mathrm{xi}$. 
sharply at $150{ }^{\circ} \mathrm{C}$, then decreased slightly with no significant variation among the different treatment times. For Pine, the MOR values showed significant variation until $170{ }^{\circ} \mathrm{C}$, and later decreased. For Larch, the MOR values decreased with both treatment temperatures and times. Thus, the MOR values changes were caused by the different chemical structures, as well as the densities, moisture contents and the directions of loading points.

Table 4 presents the MOR of the heat treated woods compared to the untreated woods for each treatment. For Larch, the maximum bending strength loss was $53.27 \%$ at a treatment of $230{ }^{\circ} \mathrm{C}$ for $6 \mathrm{~h}$. For Pine, the maximum bending strength loss was $41.32 \%$ at a treatment of $230^{\circ} \mathrm{C}$ for $4 \mathrm{~h}$. For Spruce, the maximum bending strength loss was $44.49 \%$ at a treatment of $190{ }^{\circ} \mathrm{C}$ for $4 \mathrm{~h}$. For Yellow poplar, the maximum bending strength loss was $33.62 \%$ at $230{ }^{\circ} \mathrm{C}$ for $4 \mathrm{~h}$. The maximum MOR decreased approximately $50 \%$ for Larch at a treatment of $230{ }^{\circ} \mathrm{C}$ for $6 \mathrm{~h}$. These results show that the samples became more and more fragile with increasing heat treatments. The reasons for decreased MORs have been extensively discussed by Boonstra et al. (2007). The degradation of hemicellulose has been proposed as the major factor for the loss of mechanical strength, especially affecting bending strength; however, the crystallization of amorphous cellulose might also play an important role. Polycondensation reactions of lignin, resulting in cross-linking, indicated positive impacts in the longitudinal direction. Furthermore, the lower equilibrium moisture content might positively affect the strength properties of heat treated wood, but this effect is superseded by the degradation of the chemical compounds. The aforementioned researchers believe that the degradation of hemicelluloses into volatile products and the evaporation of extractives are the main reasons for density decreases. It was considered that the variations in bending strength loss between the four species were due to the different chemical compositions of each.

\section{Relationships between color variables and physi- cal properties}

We analyzed the relationship between the color variables and the physical properties, such as the mass loss, EMC, swelling and MOR, using a multiple stepwise regression based on the most basic color variable $\mathrm{L}^{*}$, with $\mathrm{a}^{*}$ and $b^{*}$ as independent variables. The mass loss, EMC, swelling and MOR have a linear relationship with $\mathrm{L}^{*}$. Slightly increasing the number of independent variables led to larger coefficients of determination $\left(\mathrm{R}^{2}\right)$, as shown in Table 5. Conversely, the multiple stepwise regression significantly improved the estimation of most of the physical properties, compared to the linear regression, changing from 0.524 to 0.829 for EMC for Larch. These results are due to the fact that the decreasing lightness $\mathrm{L}^{*}$ was affected the most, with the chemical changing having less of an effect on $\mathrm{a}^{*}$ and $\mathrm{b}^{*}$.

Higher $\mathrm{R}^{2}$ values were found for the mass loss for Spruce and Larch, and the EMC for Spruce, Yellow poplar and Larch. Lower $\mathrm{R}^{2}$ values were found for the mass loss for Yellow poplar and Pine, the EMC in Pine, the swelling for all four species and the MOR in Pine and Larch. The $\mathrm{R}^{2}$ values for Spruce and Yellow poplar varied between 0.074 and 0.043 , respectively. Based on these results, strong correlations were found between the three color variables ( $\mathrm{L}^{*}, \mathrm{a}^{*}$ and $\mathrm{b}^{*}$ ) and the mass loss, EMC and swelling. Thus, color change, mass loss, EMC and swelling are all caused by the degradation of chemical compositions, especially those affected by the degradation of hemicelluloses. The degradation of hemicelluloses is the main determinant of color changes, mass losses, EMC and swelling. In additionally, the different chemical compositions slightly affect the change in mechanical properties. For instance, the dissolution, oxidization, decomposition and migration of extractives affect color change, and the EMC and swelling are more or less affected by lignin. The MOR changes are mainly due to chemical changes such as the degradation of hemicellulose, the crystallization of amorphous cellulose and the polycondensation reactions of lignin. A lower equilibrium moisture content leads to a lower moisture content and a lower density might affect the mechanical properties. Therefore, it is possible that the basic color variables $\left(L^{*}, a^{*}\right.$ and $\left.b^{*}\right)$ in the heat treatment of wood can predict the mass loss, EMC and swelling. Conversely the color variables cannot accurately determine the MOR in terms of bending strength.

\section{CONCLUSION}

Four different species of wood were heat-treated at five different temperatures of $150{ }^{\circ} \mathrm{C}, 170{ }^{\circ} \mathrm{C}, 190{ }^{\circ} \mathrm{C}, 210^{\circ} \mathrm{C}$ and $230^{\circ} \mathrm{C}$, and three different times of $2 \mathrm{~h}, 4 \mathrm{~h}$ and $6 \mathrm{~h}$. We analyzed the relationship between the three basic color variables and the physical properties changes, with the following results:

1. The color specimens darkened with heat treatment. $\mathrm{L}^{*}$ decreased with increasing temperatures and times, and $a^{*}$ and $b^{*}$ increased initially and then later decreased. Thus, the specimens initially became more red and yellow and then lost those colors. These results correspond to the increase in $\Delta \mathrm{E}$. Temperature affects wood color more than time.

2. At a temperature of $190^{\circ} \mathrm{C}$, the mass loss increased slightly with increasing temperatures and the treatment time for all species then increased sharply with increasing the temperature and treatment time. And, temperature has more affect than time on mass loss.

3. The equilibrium moisture content (EMC) decreased increasing temperature and treatment times for all of the samples, with a maximum EMC loss for all species of approximately $50 \%$ at $230{ }^{\circ} \mathrm{C}$.

4. Water absorption swelling initially increased slightly, decreasing later with increased temperatures. The smallest water sorption appeared at $230^{\circ} \mathrm{C}$, and the most decreasing water absorption ranged from $15.57 \%$ to $33.48 \%$, compared to the untreated samples. The volumetric swelling value was nearly equal to the sum of the cross-sectional and longitudinal swelling values.

5. The modulus of rupture (MOR) values for Spruce and Yellow poplar decreased, but these for Pine and Larch 
increased slightly at the initial stage of heat treatment; however, the MOR values largely decreased at the later stages.

6. The physical properties and the MOR have a linear relationship with $\mathrm{L}^{*}$, and increasing the number of independent variables led to larger coefficients of determination $\left(\mathrm{R}^{2}\right)$. The MOR changes were affected by the density and moisture content; therefore, the coefficients of determination $\left(\mathrm{R}^{2}\right)$ were lower than others.

\section{ACKOWLEDGEMENT}

This work was supported by an SMBA (Small and Medium Business Administration) Grant in 2009 and research funds of Chonbuk National University in 2010.

\section{REFERENCES}

Bekhta, P. and P. Niemz 2003 Effect of high temperature on the change in color, dimensional stability and mechanical properties of spruce wood. Holzforschung. 57: 539-546

Bhuiyan, T. and N. Hirai 2005 Study of crystalline behaviour of heat treated wood cellulose during treatments in water. $J$. Wood Sci. 51: $42-47$

Boonstra, M. and B. Tjeerdsma 2006 Chemical analysis of heat treated softwoods. Holz Roh Werkst. 64: 204-211

Boonstra M. and J. Blomberg 2007 Semi-isostatic densification of heat treated radiata pine. Wood Sci. Technol. 41: 607-617

Bruno Esteves, Antonio Velez Marques, Idalina Domingos, and Helena Pereira 2008 Heat-induced color changes of pine and eucalypt wood. Wood Sci. Technol. 42: 369-384

Carrier, B., F. Carrier, G. Janin, Dp. Kamdem, M. Irmouli and J. Goncalez 2002 Study of industrial boiling process on walnut color: experimental study under industrial conditions. Holz Roh-Werkst. 60: 259-264

C. H. S. Del Menezzi, I. Tomaselli, E. Y. A. Okino, D. E. Teixeira, and M. A. E. Santana 2009 Thermal modification of consolidated oriented strandboards: effects on dimensional stability, mechanical properties, chemical composition and surface color. Eur. J. Wood prod. 67: 383-396

Evteves, B., J. Graca and Pereira, H. 2008 Extractive composition and summative chemical analysis of thermally treated eucalypt wood. Holzforschung. 62: 344-351

Esteves, B. A., Velez Marques, I. Domingos and H. Pereira 2007 Influence of steam heating on the properties of pine (Pinus pinaster) and eucalypt (Eucalyptus globulus) wood. Wood Sci Technol. 41: 193-207

Jamsa, S. and P. Viitaniemi 2001 Heat treatment of wood-Better durability without chemicals. In: Proceedings of Special Seminar held in Antibes, France

Johansson, D. and T. Moren 2006 The potential of color measurement for strength prediction of thermally treated wood. Holz Roh-Werkst. 64: 104-110

Jung H. S. 1986 Wood physics, Seoul National University Press

Kamdem, D., A. Pizzi and A. Jermannaud 2002. Durability of heat treated wood. Holz Roh-Werkst. 60: 1-6

Kubojima, Y., T. Okano and M. Ohta 2000 Bending strength of heat-treated wood. $J$ Wood Sci. 46: 8-15

Mazela, B., R. Zakrzewski, W. Grze'skowiak, G. Cofta and M. Bartkowiak 2004 Resistance of thermally modified wood to basidiomycetes. EJPAU, Wood Technology. 7(1)

Metsa-Kortelainen, S., T. Antikainen and P. Viitaniemi 2006 The water absorption of sapwood and heartwood of Scots pine and Norway spruce heat-treated at $170{ }^{\circ} \mathrm{C}, 190{ }^{\circ} \mathrm{C}, 210^{\circ} \mathrm{C}$ and $230^{\circ} \mathrm{C}$. Holz Roh-Werkst. 64(3): 192-197

Mitsui, K., H. Takada, M. Sugiyama and R. Hasegawa 2001 Changes in the properties of light-irradiated wood with heat treatment: Part 1 Effect of treatment conditions on the change in color. Holzforschung. 55: 601-605

Nuopponen, M., Vuorinen, T., Jamsa, S., and Viitaniemi, P. 2004 Thermal Modifications in softwood studied by FT-IR and UV Resonance Raman spectroscopies. J. wood Chem Technol, 24: $13-26$

Rapp A. O. 2001 Review on heat treatments of wood. In Proceedings of the European Cooperation in the Field of Scientific and Technical Research. COST Action E22. Antibes, France

Sehlstedt-Persson, M. 2003 Color responses to heat treatment of extractives and sap from pine and spruce. 8th International IUFRO Wood Drying Conference, Brasov., romania, 459-464

Shuichi, D., A. Masakazu, Y. Shigeru and Y. Kurimoto 2005 Changes of decay and termite durabilities of Japanese larch(Larix leptolepis) wood due to high-temperature kiln drying processes. J. Wood Sci, 51: 526-530

Sini Metsa-Kortelainen, Toni Antikainen, and Pertti Viitaniemi 2006 The water absorption of sapwood and heartwood of Scots pine and Norway spruce heat-treated at $170^{\circ} \mathrm{C}, 190^{\circ} \mathrm{C}$, $210^{\circ} \mathrm{C}$ and $230^{\circ} \mathrm{C}$. Holz Roh-Werkst, 64: $192-197$

Sivonen, H., S. Maunu, F. Sundholm, S. Jamsa and P. Viitaniemi 2002 Magnetic Resonance Studies of Thermally Modified Wood. Holzforschung, 56: 648-654

Stamm, A. J., H. K. Burr and A. Kline 1946. Staybwood-Heat stabilized wood. Ind Eng Chem, 38(6): 630-634

Stamm, A. J. 1956 Thermal degradation of wood and cellulose. Ind Eng Chem, 48(3): 413-417

Sundqvist, B. and T. Moren 2002 The influence of wood polymers and extractives on wood color induced by hydrothermal treatment. Holz Roh-Werkst, 60: 375-376

Sundqvist, B. 2002 Color response of Scots pine (Pinus sylvestris), Norway spruce(Picea abies) and birch (Betula pubescens) subjected to heat treatment in capillary phase. Holz Roh-Werkst, 60: 106-114

Terziev, N., J. Boutelje and O. Soderstrom 1993 The infulence of drying schedules on the redistribution of low-moiecular sugars in Pinus sylvestries L. Holzforschung, 47: 3-8

Terziev, N. 1995 Migration of low-molecular sugars and nitrogenous compounds in Pinus sylverstris L. during kiln and air drying. Holzforschung, 49: 565-574

Theander, O., J. Bjurman and J. B. Boutelje 1993 Increase in the content of low-molecular carbo-hydrates at the lumber surfaces during drying and correlations with nitrogen content, yellowing and mould growth. Wood Sci. Technol, $\mathbf{2 7}$ 381-389

Tjeerdsma, B., M. Boonstra, M., A. Pizzi, P. tekely and H. Militz 1998 Characterisation of thermally modified wood: molecular reasons for wood performance improvement. Holz RohWerkst, 56: $149-153$

Tjeerdsma, B. and H. Miliz 2005 Chemical changes in hydro heat wood: FTIR analysis of combined hydro heat and dry heat-treated wood. Holz Roh-Werkst, 63: 102-111

Varga, D. and Van der Zee ME. 2008 Influence of steaming on selected wood properties of four hardwood species. Holz Roh-Werkst, 66: 11-18

Viitaniemi, P., S. Jamsa and H. Viitanen 1997 Method for improving biodegradation resistance and diemnsional stability of cellulosic products. United States Patent 5678324

Wikberg, H. and S. Maunu 2004 Characterisation of thermally modified hards and softwoods by 13C CPMAS NMR. Carbohydr Polym. 58: 461-466 
